\title{
Geological Association of Canada 2000 Annual Technical Meeting Newfoundland Section
}

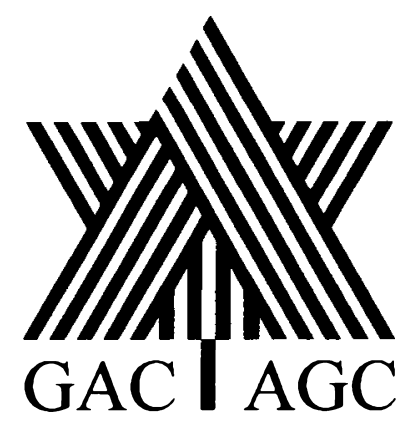

\section{ABSTRACTS}

Recent advances in resource evaluation techniques in the earth sciences

\author{
February $22-23,2000$ \\ Department of Earth Sciences \\ Memorial University of Newfoundland \\ St. John's, Newfoundland
}




\title{
Paleontological resources management
}

\author{
W.D. Boyce \\ Newfoundland Department of Mines and Energy, Geological Survey, PO Box 8700, St. John's, NF AlB 4J6 \\ $<w d b @ z e p p o . g e o s u r v . g o v . n f . c a>$
}

As the beginning of the twenty-first century and the third millennium approaches, paleontology is more popular than ever. It is one of the forces driving the renewed interest in the exploration of Mars. Here on Earth, it is rapidly becoming a major component of eco-tourism. There is a dark side to this popularity, however. In early September 1998, a trio with a rented U-Haul trailer from Buffalo, New York, attempted to remove Late Precambrian fossils from the vicinity of the Mistaken Point Ecological Reserve, using a pivotable rock saw. They were thwarted by concerned locals, who are currently developing eco-tourism proposals based on the fossils. As a direct consequence of the incident, the province is currently revising the Historic Resources Act to include protection for fossils; currently, fossils are only protected under the Wilderness and Ecological Reserves Act. The challenge is to identify present and future paleontological resources worthy of protection, provide effective, flexible legislation without introducing undue bureaucracy, and maintain a balance between the interests of science, education, eco-tourism, etc. Paleontological resources management is greatly enhanced when the local populace are informed and on-side.

\section{Aggregate resource assessment techniques}

\author{
Dan Bragg \\ Newfoundland Department of Mines and Energy, Mineral Lands Division, PO Box 8700, St. John's, NF AIB 4J6 \\ $<$ djb@zeppo.geosurv.gov.nf.ca $>$
}

Poor techniques currently being used in the search for, and assessment of, construction aggregate often lead to poor quality of material being used in road construction, as evidenced by premature deterioration of asphalt. The techniques that should be used to insure a proper assessment are investigated here.

Aggregate resource assessment involves research techniques from geology and geotechnical engineering to determine the quality of a resource. This paper will deal with such techniques as the initial Site evaluation, petrographic analysis, geological structures, sedimentary structures in quaternary deposits and investigating geotechnical properties of the resource.

Once the resource assessment is completed, a quality appraisal may be assigned to the deposit or resource and a recommendation made for its use as asphalt, Class A and B material, subgrade, concrete aggregate or fill material.

\section{Transformation of Fe-Ti gabbro to coronite, eclogite, and amphibolite in the Baie du Nord segment, Manicouagan Imbricate zone, eastern Grenville province: evidence for high heat flow in the lower crust during orogenesis}

\author{
Richard Cox and Aphrodite Indares \\ Department of Earth Sciences, Memorial University of Newfoundland, St. John's, NF AlB $3 X 5$ \\ $<$ p37rac@plato.ucs.mun.ca $>$
}

Fe-Ti gabbro from the Baie du Nord Segment of the Manicouagan Imbricate zone, metamorphosed under high-P-T conditions during the Grenvillian orogeny, has been the focus of a detailed micropetrological study. Textures and mineral chemistry suggest that the mineral assemblages represent progressive stages of metamorphic transformation resulting in the formation of coronas, pseudomorphs after igneous phases (transitional), and true granoblastic eclogite. The transitional and eclogitic samples also have coronas developed locally around igneous xenocrysts of plagioclase and olivine. Coronitic $\mathrm{Fe}-\mathrm{Ti}$ gabbro is transformed to amphibolite at deformed margins and contains clinopyroxene-bearing leucosomes with garnet poikiloblasts that are indicative of high-PT dehydration melting. Interpretation of garnet zoning and thermobarometry suggest that the highest-P-T conditions are recorded by coronas around xenocrysts (ca. $720-800^{\circ} \mathrm{C}$ at 14-17 kbar) and garnet-clinopyroxene cores in granoblastic assemblages (ca. $740-820^{\circ} \mathrm{C}$ at $13-17 \mathrm{kbar}$ ) in the eclogitic samples. Re-equilibration during the early stages of exhumation at high- $\mathrm{T}$ conditions $\left(>700^{\circ} \mathrm{C}\right)$ affected all samples, and is indicated by the widespread development of pargasite-bearing plagioclase collars in the coronitic and transitional metagabbro and by widespread re-equilibration of the eclogite giving lower P-T estimates at grain boundaries. However, the difference in calculated $P$ conditions between coronite and eclogite samples is consistent with increasing pressure (depth) from the coronite (11-13 kbar) to the eclogite (13-17 kbar). The P-T conditions recorded by these rocks define an apparent isothermal P-T path. In fact, this is a steep metamorphic field gradient, indicating that all the samples experienced temperatures in excess of $800^{\circ} \mathrm{C}$ both during and shortly after peak metamorphism over a range of depths (ca. $65-35 \mathrm{~km}$ ). This is turn suggests high heat flow through this segment of the lower crust during the Grenvillian orogeny. 


\title{
$\mathrm{U}-\mathrm{Pb}$ geochronology and geologic significance of the two oldest known mafic dyke swarms on earth: 3659 Ma Inaluk dykes and 3490 Ma Tarssartôq dykes, southern west Greenland
}

\author{
J.L. Crowley', R.V. White ${ }^{2}$, J.S. Myers' and G.R. Dunning' \\ 'Department of Earth Sciences, Memorial University of Newfoundland, St. John's, NF AlB $3 \times 5$ \\ <jcrowley@sparky2.esd.mun.ca> \\ ${ }^{2}$ GEUS, Thoravej 8, DK 2400, NV, Copenhagen, Denmark
}

Mafic dyke swarms are valuable time markers in the Archean craton of southern west Greenland. The Ameralik dykes in the Godthåbsfjord region are particularly useful for differentiating early Archean rocks and tectonic events from late Archean rocks and events. The only age constraint on these dykes in their type locality (outer Godthabsfjord) is that they intruded between suites of rocks formed at $3.6 \mathrm{Ga}$ and 3.0 $\mathrm{Ga}$. In outer Godthåbsfjord, the dykes were strongly deformed and metamorphosed in the late Archean.

In the vicinity of Isua, located $160 \mathrm{~km} \mathrm{NW}$ of outer Godthåbsfjord, a dyke swarm that has been correlated with the Ameralik swarm was largely unaffected by late Archean events. The dolerite dykes at Isua, known as the Tarssartôq dykes, are least deformed to the north of the Isua greenstone belt, where they cut tonalitic gneiss with a protolith age of $3700 \mathrm{Ma}$. The dykes form two swarms, an E-W swarm that is cut by a N-S swarm.

$\mathrm{U}-\mathrm{Pb}$ accessory minerals are rare in these dykes, but a coarser grained and more felsic dyke with an E-W orientation contains abundant zircon, zircon overgrowths of baddeleyite, and baddeleyite. Three single grain $\mathrm{U}-\mathrm{Pb}$ analyses of zircon and zircon overgrowths of baddeleyite yield a discordia line with upper and lower intercepts of $3490 \pm 2$ and $1305 \pm 19 \mathrm{Ma}$ $(M S W D=0.04)$. Discordance is $3-18 \%$. Three other single grain analyses of zircon overgrowths of baddeleyite and baddeleyite yield ages that lie just above or below the discordia. The upper intercept of $3490 \pm 2 \mathrm{Ma}$ is interpreted as the crystallization age of the E-W Tarssartôq dykes.

It remains unproven whether the Ameralik dykes in outer Godthåbsfjord are also $3490 \mathrm{Ma}$. However, it is certain that metamorphism and deformation of gneisses north of the Isua greenstone predate $3490 \mathrm{Ma}$ and that rocks adjacent to and within the greenstone belt were metamorphosed and deformed after $3490 \mathrm{Ma}$.

The host gneisses of the Tarssartôq dykes contain an older dyke swarm, known as the Inaluk dykes, which were metamorphosed and deformed before intrusion of the Tarssartôq dykes. In low strain zones, it is recognized that the Inaluk dykes postdate an older gneissosity in the host gneiss yet they were strained by the deformation that formed the regional gneissosity. Four $\mathrm{U}-\mathrm{Pb}$ analyses of single zircon grains with an igneous morphology yield concordant ages of $3659 \pm 2 \mathrm{Ma}$, the interpreted crystallization age of the Inaluk dykes.

This study of the dykes is being carried out in conjunction with our detailed studies of the field relationships, structure, petrology, and geochemistry of the diverse components of the gneisses and greenstone belt at Isua. These studies will further improve our knowledge of the geological history of Earth's oldest preserved crust.

\section{Seismic imaging of the Bjerkreim Layered Intrusion}

\author{
Sharon Deemer \\ Department of Earth Sciences, Memorial University of Newfoundland, St. John's, NF AlB $3 X 5$ \\ <ecsoot@waves.esd.mun.ca>
}

Seismic data collected over the Bjerkreim Layered Intrusion illustrates the capability of the seismic reflection technique to image the layering in these crystalline rocks. Strong continuous reflections were recorded at megacyclic unit boundaries that correspond to large-scale changes in bulk composition of the magma chamber resulting from progressive crystallization as well as the reversals that occur when major influxes of new magma enter the chamber. Modelling of some other mapped layered intrusions further illustrates the reflective nature of intrusions with varying composition.

\section{Integration of geosciences for resource evaluation at Hibernia}

\author{
John D. Evans, Iain Sinclair, Robert Stokes and Will DaSie \\ Hibernia Management Development Company Ltd., St. John's, NF \\ <john.evans@hibernia.ca>
}

A primary goal of the geoscience team at Hibernia is to build accurate and robust models of the field. These models, derived through a process of integrating all our data, provide the basis for strategic and operational planning in order to optimize development of the resources. Detailed resource estimates are one of the key products of these models. Currently we use with both traditional 2D surface based models and 3D statistical models for generating resource assessments. We also utilize probabilistic methods for characterizing the uncertainty in these resource estimates. 
At Hibernia our two primary development objectives are the reserves in the lower Hibernia Formation and the Ben Nevis/Avalon formations. Each has different structural, stratigraphic, petrophysical and fluid uncertainties that we are currently addressing to improve our earth models and resource assessments. In the Hibernia Formation, we have drilled many of the larger fault blocks and are focussing our efforts on improving our understanding of subtler stratigraphic and structural complexities that impact the development of both these larger blocks and smaller blocks yet to be drilled. In the Ben Nevis/Avalon formations, we are just now drilling our first development well and are updating our resource assessment on the basis of revised structural and stratigraphic interpretations following the reprocessing of our 1991 3D seismic data. For both reservoirs one of our key objectives is to better characterize the distribution of our resources relative to fault and stratigraphic discontinuities, with the ultimate goal of optimizing the recovery of these resources with the fewest number of wells.

Some of our current processes and technical work, with a focus on our resource evaluation issues, will be presented.

\title{
Re-evaluating the role of lithogeochemistry in base- and precious-metal exploration
}

\author{
Alan Galley \\ Mineral Resources Division, Geological Survey of Canada, 680-601 Booth Street, Ottawa, ON KIA OE8 \\ <agalley@NRCan.gc.ca>
}

The last ten years lithogeochemistry is playing an increasingly dominant role in many exploration programs for several reasons: 1) A better understanding of the major and trace element and isotopic characteristics of tectonic regimes containing certain deposit types, and an interest by petrologists in communicating these findings to the explorationist; 2) A refinement and proliferation of techniques used to identify geochemical gradients within hydrothermal alteration systems; 3) Increasing accuracy and cost effectiveness in analytical methods available to commercial laboratories; and 4) The availability of inexpensive, powerful hardware and software to allow the interrogation of lithogeochemical data and its incorporation in layered datasets. This is perhaps a good time to re-evaluate the relative importance of lithogeochemistry within a balanced exploration program, and how it can be integrated more effectively with field observations, petrography, and mineral chemistry to increase efficiency and cost effectiveness.

The role of lithogeochemistry in an exploration program is to: 1) define the composition of the rock suite hosting mineralization; 2) use these compositions to define petrologic affinities, and thereby gain a better understanding of the depositional environment and conditions; and 3) to recognize alteration trends that can be used as vectors towards potential ore deposits. Whereas understanding the criteria that define various rock types is relatively easy, optimization of petrologic and alteration data requires an increasingly detailed and in-depth knowledge of petrogenesis and the systematics of magmatic-hydrothermal fluids, with criteria varying between deposit types. The danger comes when the criteria become too complex, resulting in confusion, mistaken conclusions, and possibly a rejection of lithogeochemistry as an effective exploration tool.

In order to avoid the ineffective use of exploration geochemistry, it is the responsibility of petrologists and hydrothermal geochemists to effectively integrate their knowledge transfer to the mineral industry with field-related geological and mineralogical parameters. Lithogeochemistry should be considered as part of a loop which starts with sound lithological, mineralogical, and structural observations, followed by petrography and geochemistry to provide a quantitative link to the field observations, with results that can be plotted on a map or drill log. Once the connection is made between field-petrographic observations and geochemical data, the confidence level is increased with respect to understanding the geological and mineralogical relationships in the field.

\section{GIS-based metallogenic studies in the Carboniferous Deer Lake basin, Newfoundland}

\author{
Jody Hodder' and Derek H.C. Wilton ${ }^{2}$ \\ 'Husky Oil, Calgary, $A B$. \\ ${ }^{2}$ Department of Earth Sciences, Memorial University of Newfoundland, St. John's, NF AlB $3 X 5$ \\ $<$ dwilton@sparky2.esd.mun.ca>
}

Gravity and magnetic residuals suggest that the basement to the basin is block faulted. The basin can be subdivided into eight distinct fault-bounded blocks based on the character of the potential field anomaly maps. The combined potential field and geochemical data indicate that some forms of mineralization within the basin occur near residual gravity and magnetic highs, whereas other forms are correlated with high magnetic gradients. The trends indicate that metallic mineralization and hydrocarbons are associated with the underlying basement topography and that the faults formed structural conduits along which hydrothermal fluids migrated. The association of bitumen with mineralizing fluids appears to have resulted from their utilization of the same regional fault systems for migration. 


\title{
The role of geochemistry in metallogeny: examples from Newfoundland, Australia, and Nunavut
}

\author{
George A. Jenner \\ Department of Earth Sciences, Memorial University of Newfoundland, St. John's, NF AlB $3 X 5$ \\ <gjenner@sparky2.esd.mun.ca>
}

In the broadest context, metallogeny and metallogenic studies serve to try and establish the relationship between the geological history of an area and its mineral deposits. Geochemistry plays an important role in metallogenic studies, addressing such issues as defining the tectonic environment of formation of volcanic and plutonic rocks, identifying more prospective horizons in a given stratigraphy, establishing correlations between units and defining a chemo-stratigraphy, identifying the source of fluids, and the age of mineralization and host rocks.

Regional scale lithogeochemical studies of CambroOrdovician volcanic rocks in the Dunnage Zone of central Newfoundland have been used to identify tectonic environments in which volcanogenic massive sulphide (VMS) deposits formed. These studies were crucial to the production of the 1:500,000 "Metallogeny of the Vestiges of lapetus, Island of Newfoundland" map, which serves as a first-order guide to VMS explorationists. More focussed lithogeochemical studies can be used to assess the potential of relatively unexplored terranes in the vicinity of a particular mining camp, for example the Buchans area.

As part of a major study on the structure and mineralization of Western Tasmania (host to the Roseberry and Mt. Lyell deposits, amongst others), a variety of geochemical techniques were used. These included standard lithogeochemical studies of volcanic and sedimentary rocks, microprobe analyses of pyrite samples, stable isotope analyses of fault zones, and detrital grain studies (including $\mathrm{U}-\mathrm{Pb}$ dating of detrital zircons). The goal of these studies was to test an established tectonic model, and help separate out the effects of late Cambrian and Devonian deformation, which mask the short-lived middle Cambrian extensional event associated with VMS deposit formation.

Geochemical studies of host rocks and mineralized occurrences in Archean greenstone belts in the western Churchill Province, Nunavut have been an important component of the metallogenic investigations. As recently acknowledged by industry, these studies have played an important role in the recent staking of 30,000 ha of land, effectively quadrupling the company's exploration area.

\section{Magmatic sulphide mineralization in the Pants Lake Intrusion, Labrador: implications for geological exploration models for Voisey's Bay-style deposits}

\author{
Andrew Kerr \\ Newfoundland Department of Mines and Energy, Geological Survey, PO Box 8700, St. John_s, NF AlB 4J6 \\ $<$ akr@zeppo.geosurv.gov.nf.ca>
}

The ca. 1322 Ma Pants Lake Intrusion (PLI) comprises several mafic intrusions emplaced into sulphide-bearing metasedimentary gneisses, about $100 \mathrm{~km}$ south of the world-class Voisey's Bay $\mathrm{Ni}-\mathrm{Cu}-\mathrm{Co}$ deposit. The PLI provides the closest analogue to the Voisey's Bay host rocks recognized to date in Labrador, and contains widespread disseminated, and, more rarely, massive magmatic sulphide mineralization. The area presents an opportunity to test and further develop geological exploration models based upon the Voisey's Bay deposits. Many critical processes seen (and inferred) in the Voisey's Bay area apparently also operated during the emplacement of the PLI. However, there are also important differences between the two areas and their evolution may not be strictly parallel.

The PLI is dominated by several different varieties of olivine-gabbro. The component intrusions are sheet-like, and range from $<50 \mathrm{~m}$ to over $600 \mathrm{~m}$ in thickness. Their presently complex geometry probably reflects the superposition of regional tilting and/or gentle folding on primary variations in their thickness and anatomy. Magmatic sulphide mineralization is ubiquitous near the basal contacts of most
PLI intrusions, and is invariably associated with distinctive, contaminated, sulphide-bearing mafic rocks that include textural equivalents of the 'basal breccias' and 'leopard troctolites' described from Voisey's Bay. There is strong evidence for assimilation of local metasedimentary gneisses, which may have provided an external source for much of the sulphur. The PLI mineralized sequences record the introduction of discrete sulphide- and fragment-bearing magma pulses into evolving, dynamic, mafic magma chambers, as suggested for the Voisey's Bay deposit. However, the PLI mineralized sequences appear to be intrusion-wide 'stratigraphic' features, and discrete mineralized feeder conduits, as documented at Voisey's Bay, have not yet been located. Ni contents at $100 \%$ sulphide are mostly lower than at Voisey's Bay, but the sulphides contain higher $\mathrm{Cu}$ and $\mathrm{Co}$ at a given $\mathrm{Ni}$ content, and consistent $\mathrm{Ni} / \mathrm{Cu}$ and $\mathrm{Ni} / \mathrm{Co}$ ratios suggest a large-scale magmatic process. There is evidence for the extraction of large quantities of $\mathrm{Ni}$ and $\mathrm{Cu}$ from these magmas by sulphide liquids. The challenge for future exploration in this area is to find out where it went! 


\title{
$\mathrm{Li}$ isotopic composition of foraminiferal tests: can we measure it using a quadrupole ICP-MS?
}

\author{
Jan Kosler \\ Department of Earth Sciences, Memorial University of Newfoundland, St. John's, NF AIB $3 X 5$ \\ $<j k o s l e r @ s p a r k y 2 . e s d . m u n . c a>$
}

Isotopic composition of lithium is potentially a powerful tracer of geochemical processes such as high-temperature magmatic differentiation, alteration of oceanic crust or fluidrock interactions. Lack of analytical techniques capable of high-sensitivity, precise, and accurate measurements in the past has precluded detailed study of $\mathrm{Li}$ isotopic composition in geological materials and its fluxes between different reservoirs. As a result, the global lithium mass balance is only poorly understood: the two major sources of oceanic lithium (expressed as $\delta^{6} \mathrm{Li}$ values calculated relative to ${ }^{6} \mathrm{Li}^{7}{ }^{7} \mathrm{Li} \mathrm{L}_{\text {-sveC }}=$ $0.0832)$ are river input from the continents $(-6$ to $-32.2 \%$ ) and high-temperature alteration of oceanic basalts $(-9 \%)$. Given the average sea water $\mathrm{Li}$ isotopic composition of $-32 \%$, additional inputs or sinks that fractionate $\mathrm{Li}$ isotopes are required to maintain a steady state of $\mathrm{Li}$ isotopes in the ocean. If a proxy for the $\mathrm{Li}$ isotopic composition of past oceans could be developed, it would provide us with invaluable information about the variation in rates of continental weathering, and/or sea floor spreading rate.

Inductively coupled plasma mass spectrometry (ICP-MS) is a technique that can provide routine, precise and accurate (and relatively cheap) measurements of $\mathrm{Li}$ isotopic composition in geological materials that need to be studied to constrain the inputs and sinks to the $\mathrm{Li}$ geochemical cycle. Using a commercially available ICP-MS quadrupole instrument equipped with a cool plasma option, isotopic composition of lithium can be measured with a within-run precision better than $0.05 \%$, and a long-term reproducibility of standards better that $1 \%$ ( 2 sigma, $\delta^{6} \mathrm{Li}$ values). Similar to other techniques that are currently in use to analyse $\mathrm{Li}$ isotopic composition, quantitative chemical separation of $\mathrm{Li}$ prior to the measurement on ICP-MS is necessary to avoid the matrixinduced isotopic fractionation and the results have to be externally corrected for mass bias and instrumental fractionation. On the other hand, the low-blank chemistry (total blank of ca. $120 \mathrm{pg} \mathrm{Li}$ ) and high Li ionisation efficiency allow precise measurements of isotopic ratios from concentrations as low as $5 \mathrm{ppb} \mathrm{Li}$. Using a low sample uptake, samples containing 5-10 ng Li can be analysed without compromising the sensitivity and length of the measurement.

We have successfully analysed $5-10 \mathrm{mg}$ samples of planktonic foraminiferal tests (Pulleniatina obliquiloculata, Globorotalia tumida and Orbulina universa) from top $2 \mathrm{~cm}$ of cores collected from Ontong-Java Plateau (western Pacific) and Ceara Rise (western equatorial Atlantic). The samples were crushed to break open the chambers and ultrasonically and chemically cleaned prior to dissolution to avoid contamination by $\mathrm{Li}$ from surface coatings or host sediment. The studied tests contain $0.7-1 \mathrm{ppm} \mathrm{Li}$ and their $\mathrm{Li}$ isotopic composition varies from -27.1 to $-57.9 \%$. Our limited data show a variable $\mathrm{Li}$ isotopic composition for Globorotalia tumida and a decrease with increasing size of the tests for the ${ }^{6} \mathrm{Li} /{ }^{7} \mathrm{Li}$ ratios in Orbulina universa. Isotopic composition of $\mathrm{Li}$ in Pulleniatina obliquiloculata is similar to that of the present day sea water and it is independent of the size of the tests, suggesting that its composition appears not to be affected by vital effects or isotopic exchange with the sediment and that it may be used as a proxy for $\mathrm{Li}$ isotopic composition of the sea water.

\section{Seismic modeling of ore bodies - massive sulphides}

\author{
K. Laletsang, J.A. Wright and C.A. Hurich \\ Memorial University Seismic Imaging Consortium (MUSIC), Department of Earth Sciences, Memorial University of \\ Newfoundland, St. John's, NF AIB $3 X 5$ \\ $<k b @$ waves.esd.mun.ca>
}

Owing to their high density compared with crystalline rocks, massive sulphide ore bodies should be excellent seismic reflectors. In contrast, attempts to image these ore bodies with reflection seismic have had limited success. One reason for this failure is that bodies are small compared with the seismic wavelengths used in conventional surveys. This leads to less than a full amplitude response being recorded. Also, if the relief on the surface of the ore body is variable, the reflection amplitudes will be attenuated. The resulting seismic response will thus consist of a complicated diffraction pattern dominated by side swipe in 2D surveys. These issues show that one is dealing with unusual data that require special processing to get a good seismic image.

We conducted 3D physical and 2D numerical seismic modelling experiments to study the seismic signature of ore bodies of complex geometry contained in a constant velocity fluid medium. The physical modelling is purely geometric and intended only to observe amplitude patterns but no amplitude analysis is envisaged. These experiments are aimed to identify the characteristic seismic expression of the ore bodies in as far as the geometry is concerned. This will help to determine the appropriate acquisition and processing parameters required to successfully image massive sulphides and similar deposits. The modelling experiments are scaled such that they mimic high-resolution 3D surveys. Records of 3,000 ms TWT, sampled at $1 \mathrm{~ms}$, with a spectral bandwidth of $20-100 \mathrm{~Hz}$ were collected for two surveys covering an area of $900 \times 300 \mathrm{~m}$, with 54000 traces each. The target was a $75 \times 37.5 \mathrm{~m}$ doughnut-shaped ore body with a variable surface relief. The ore body was at different depths for each recording. 
We find that because the signal consists of diffractions with a moveout of the background velocity, which are hence parallel to the first breaks, it becomes essentially impossible to separate this signal from the latter when the ore body is shallow. A simple analogy with the real world shows that this commonly occurs, not because the ore body is shallow, but because the background velocity is high.

\title{
Pervasive migration of magma through the crust
}

\author{
A.M. Leitch' and R.F. Weinberg ${ }^{2}$ \\ 'Department of Earth Sciences, Memorial University of Newfoundland, St. John's, NF AlB $3 \times 5$ \\ $<$ aleitch@music.esd.mun.ca> \\ ${ }^{2}$ NEG-LABISE, Departamento de Geologia, Universidade Federal de Pernambuco, Recife, Pernambuco, 50732-970, Brazil
}

The migration of magma through the crust from deeper, hotter levels affects the composition and temperature of the crust, and so understanding mechanisms of magma migration help us to understand crustal structure and evolution. Two different mechanisms have been extensively studied: dyking and diapirism. Pervasive migration is an alternative to these.

The mechanism by which magma migrates depends on the properties of the magmas and conditions in the crust. Large quantities of fluid magma can migrate quickly through cracks in brittle crust by dyking. Diapirism, where a large blob of magma squeezes upward through plastically deforming surroundings, is favoured when the magma is very viscous and the crust is ductile. In both dyking and diapirism magma transport is strongly localized into one or maybe several distinct pathways.

"Pervasive" migration is the motion of magma through an extensive network of channels. It involves an intimate contact and efficient heat transfer between the magma and the country rock, and therefore requires that the country rocks be at temperatures above the magma solidus. Granite magma injection complexes, which are common in hot crustal terranes, are thought to result from magma migrating pervasively through an interconnected network of blobs and sheets, of scales varying between millimetres and tens of metres. At least four mechanisms control pervasive magma migration: a) tectonic pumping; b) pervasive flow through hot, low viscosity country rocks; c) volatile-driven intrusion, where magma follows volatile-rich phases; and d) small-scale local dyking.

Although the high-temperature requirement may seem very restrictive, we envisage a feedback mechanism whereby heat advected with early magma batches will warm the crust, allowing later batches to reach shallower levels. We explored this idea with a simple conceptual and numerical model in order to judge its viability. We found that pervasive migration is an efficient way of heating the lower crust, which can result in a several kilometre thick injection complex formed by approximately 50-50 original crust and magma.

\section{Tectonomagmatic evolution of the northwest Reindeer zone, Trans-Hudson orogen, Reindeer Lake, Saskatchewan}

\author{
T.G. MacHattie', D. Corrigan ${ }^{2}$ and G.A. Jenner' \\ 'Department of Earth Sciences, Memorial University of Newfoundland, St. John's NF AlB $3 X 5$ \\ $<$ t85tgm@morgan.ucs.mun.ca $>$ \\ ${ }^{2}$ Geological Survey of Canada, Continental Geoscience Division, 615 Booth Street, Ottowa, ON KIA OE9
}

The Trans-Hudson orogen is a major Early Proterozoic suture between the Archean Rae-Hearne and Superior cratons of the western Churchill Province. Reindeer Lake transects a major portion of the Trans-Hudson orogen in northern Saskatchewan (northwest Reindeer zone). Exposed from north to south are: (1) reworked Archean crystalline basement; (2) a continental arc batholith (Wathaman Batholith); and (3) a mainly juvenile volcanic arc terrane (La Ronge Domain).

La Ronge Domain metavolcanic rocks $(1910-1880 \mathrm{Ma})$ are characterized by arc type geochemical signatures. Compositions are dominantly mafic to intermediate, ranging from low-K tholeiitic to medium/high-K calc-alkaline series types. Nd isotopic data from the metavolcanic rocks indicates a predominantly depleted mantle source region, having $\varepsilon$ - $\mathrm{Nd}$ values ranging from approximately +2.5 to +5 . A series of banded dioritic to granitic orthogneiss dated at $1890 \mathrm{Ma}$ are coeval with the metavolcanic rocks and also have juvenile $\varepsilon$ $\mathrm{Nd}$ signatures $(\approx+4)$.
The Wathaman Batholith $(1860-1850 \mathrm{Ma})$ is a calcalkaline continental arc batholith ranging in composition from gabbro to granite, although it is mostly composed of coarse grained to K-feldspar porphyritic-megacrystic, hornblendebiotite granodiorite. Nd isotopic compositions range from mantle-like values $(\varepsilon-\mathrm{Nd} \approx+3)$ for mafic rocks to values as low as $\varepsilon-\mathrm{Nd} \approx-5$ for more granitic compositions. The data are consistent with bulk mixing between mantle and crust, probably focussed at the crust-mantle boundary or within the lower crust. A correlation between decreasing $\varepsilon$-Nd $(\approx-2$ to 5 ) and increased fractionation within the suite is best explained by mid-crustal (current exposed emplacement depth) assimilation and fractional crystallization processes. An increased crustal component to the magmas formed in the northern portion of the batholith can be seen in the major and trace element geochemistry. As the exposed Archean basement is approached, the relative abundances of some low 
field strength elements $(\mathrm{K}, \mathrm{Rb}, \mathrm{Ce}$, total $\mathrm{REE}$ and $\mathrm{Pb})$ as well as high field strength elements $(\mathrm{Y}, \mathrm{Nb}, \mathrm{Zr}$ and $\mathrm{Th})$ increase, indicating a larger crustal component to the magmas.

Plutons within the La Ronge Domain group mainly within the $1860-1846 \mathrm{Ma}$ age range and are thus predominantly coeval with the emplacement of the Wathaman Batholith. On Reindeer Lake plutons range in composition from diorite to granite, although quartz diorites, tonalites and granodiorites predominate. Geochemical data are consistent with a volcanic arc source for the plutons. Nd isotopes range from mantle like values $(\varepsilon-\mathrm{Nd} \approx+5)$ to values as low as $\varepsilon-\mathrm{Nd} \approx-4$, indicating a significant older crustal component to some magmas. Based on field relationships and geochronological data it is believed that many of these plutons are related to the Wathaman Batholith with differences in chemical and isotopic properties due to their emplacement predominantly within the accreted arc terranes.

\title{
Resources of a different kind: application of geochemical analytical techniques to archaeological research
}

\author{
Cathy Mathias \\ Department of Anthropology, Memorial University of Newfoundland, St. John's, NF AlB $3 X 5$ \\ <cmathias@morgan.ucs.mun.ca>
}

Both conservators and archaeologists have come to rely on the analytical tools and techniques used by earth scientists to aid in the identification and understanding of Newfoundland and Labrador's archaeological resources. From elemental mapping techniques to bulk artifact XRF analysis, the Ferryland artifact collection is currently being examined by both students and researchers in an attempt to piece together the past. This paper describes the methods and techniques being used to assess both the burial environment, artifact condition and artifact composition for a seventeenthcentury colonial site at Ferryland, Newfoundland. Results of the chemical characterization of the burial environment and iron and slag composition will be discussed as well as current projects examining the countries of origin for tin-glazed earthenware, terra sigillata ware, silver cuff-links and smoking pipes.

Characterization of soil samples involved chemical analysis by XRF, ICP-MS and soil solution ion activity by a $\mathrm{pH}$ meter, conductivity meter and a potentiostat. The identification of mineralogy was performed using XRD. Analyses of iron nail samples were performed using electron microscopy. Ceramics and clay pipes have been examined using LAM-ICP-MS and ICP-MS analytical tools. Problems obtaining suitable standards for archaeological materials and developing sample holders for non-destructive analyses will be briefly discussed.

The results for the burial environment examination indicate that iron preservation is linked to soil porosity, $\mathrm{pH}$, conductivity, corrosion rate, and $\mathrm{Cl}$ concentrations. The slag analysis indicated that both charcoal and coal were used as a fuel source by the Ferryland blacksmith. The country-of-origin research is ongoing; however, available results will be presented.

\section{Geophysical mapping of a shallow contaminant plume in thin glacial till, Terra Nova waste disposal site, northeast Newfoundland}

\author{
Hugh G. Miller' and G. Keith Guzzwell ${ }^{2}$ \\ 'Department of Earth Sciences, Memorial University of Newfoundland, St. John's, NF AlB $3 X 5$ \\ $<$ hmiller@waves.esd.mun.ca> \\ ${ }^{2}$ Newfoundland Department of Environment and Labour, PO Box 8700, St. John's, NF AlB 4J6
}

Geophysical techniques have been used to map the lateral extent of a groundwater contaminant plume in a region of thin glacial till overburden at a domestic waste disposal site in Newfoundland. This site is typified by waste cells that have significant quantities of material above the water table.

VLF-EM tilt angle, VLF-Resistivity and terrain conductivity data were collected at 227 stations on a grid with station and line spacing of $15.2 \mathrm{~m}$. The depth to bedrock at each of the ten water monitoring wells located on the site was known from drilling and used to derive the top layer resistivity distribution over the grid. This resistivity was then used in an algorithm to determine the depth to bedrock at each grid point and to produce a bedrock topography map. Two bedrock channels, along which contaminant can flow down slope, have been identified, one on each side of the site. The presence of contaminant in these channels is identified from the terrain conductivity data and the processed VLF tilt angle data.

Ground-probing radar (GPR) data were collected along the road traversing the site. The GPR data clearly indicate the boundaries of the waste cells, but bedrock cannot be unambiguously discerned.

The results from the geophysical surveys are highly correlated with chloride ion concentrations in water samples from the wells in the study area. 


\title{
Building GIS databases of digital geoscience data coverage for Newfoundland and Labrador
}

\author{
L.W. Nolan' and A. Bassan ${ }^{2}$ \\ ${ }^{\prime}$ Newfoundland Department of Mines and Energy, Geological Survey, PO Box 8700, St. John's, NF AlB 4J6 \\ <'lrn@zeppo.geosurv.gov.nf.ca> \\ ${ }^{2}$ MITI Information Technology Inc., PO Box 8595, St. John's, NF AlB 3P2
}

The Geological Survey of Newfoundland and Labrador has been collecting and organizing georeferenced databases of geological information in a variety of computer formats over the past ten years. As the size and number of these databases has grown it has become increasingly important that digital techniques are used to manage this information and apply it effectively to mineral exploration. Dramatic changes in digital information and communications technology over this decade are completely transforming the way in which geological surveys throughout the world manage and disseminate their geoscience knowledge. In response to these changes and client needs, the Geological Survey has developed a data model (Geolegend) for the Survey's digital geology maps and we are now working on implementing the North American Geological data model for the Canadian Geoscience Knowledge Network (CGKN) project. Interface tools are also being developed that will allow clients to create custom geological maps based on these data models on stand alone pc-based systems and through web-based systems.

\section{The potential of flood basalts for hosting magmatic sulphide deposits: an application of exploration criteria to the Sverdrup basin, Nunavut, Canadian Arctic}

\author{
Marie-Claude Williamson \\ Geological Survey of Canada (Atlantic), Bedford Institute of Oceanography, PO Box 1006, Dartmouth, NS, B2Y $4 A 2$ \\ $<$ mcw@agc.bio.ns.ca $>$
}

It is now widely accepted that flood basalt provinces are important targets in the search for $\mathrm{Ni}-\mathrm{Cu}$ sulphide ores. These ores may also contain concentrations of the platinum-group elements (PGE) that are of economic interest. As a result, mining companies now conduct extensive mineral exploration programs in large igneous provinces associated with continental rifting. We describe a GSC project under development that will examine the potential of the Sverdrup Basin magmatic province (SBMP) for hosting $\mathrm{Ni}-\mathrm{Cu}$ sulphide deposits, by integrating three types of geoscience information: field observations and mapping; petrological and geochemical data; and the results of aeromagnetic surveys. The SBMP is located in the Canadian Arctic islands, and consists of hypabyssal intrusive sheets and dykes, flood basalts, and central volcanoes that were emplaced during a period of approximately $60 \mathrm{Ma}$, starting in the Early Cretaceous. The volume of magma erupted in the east-central part of the Sverdrup Basin has been estimated at $10-20,000 \mathrm{~km}^{3}$, making the province comparable in scale to the Columbia River basaltic province of the western U.S. The volume of magma intruded as sills and dykes is at least an order of magnitude larger, a characteristic of many flood basalt provinces associated with continental breakup. In this talk, we present a summary of the tectonic and magmatic history of the SBMP; compare the attributes of the SBMP with those of other flood basalt provinces hosting $\mathrm{Ni}-\mathrm{Cu}$-PGE deposits; and outline the rationale, objectives, and methods of the new project.

The Sverdrup Basin is a northeast-trending, intracratonic basin that extends along the Arctic polar margin from the northern tip of Ellesmere Island to Prince Patrick and Melville Islands. It is $1300 \mathrm{~km}$ long and $400 \mathrm{~km}$ wide (after compressive deformation), and contains up to $13 \mathrm{~km}$ of
Carboniferous to Tertiary strata. The basin originated during a Carboniferous-Early Permian rifting event accompanied by minor, episodic volcanic activity of alkaline character. Renewed rifting during the Cretaceous led to widespread magmatism in areas close to the Mesozoic depocentre. As a result, the sedimentary succession is intruded by a large number of mafic sills and dykes, most of which have not been mapped in detail. Volcanic successions, however, are included on recent 1:250,000 geological maps compiled by the Geological Survey of Canada, and their Cretaceous ages have in many cases been confirmed by ${ }^{40} \mathrm{Ar} /{ }^{39} \mathrm{Ar}$ radiometric dating. The peak of volcanic activity was marked by the emplacement of flood basalts during the Albian and is contemporaneous with the age of the breakup unconformity in the Canadian Arctic Islands. The volcanic nature of the Alpha Ridge also suggests a tectonic link with the opening of the Arctic ocean. During the Late Cretaceous and earliest Tertiary, bimodal volcanic rocks were emplaced along the northern margin of the Sverdrup Basin. Following the waning of igneous activity, the basin was segmented and deformed during the Eurekan Orogeny, producing a foreland-style fold and thrust belt cut by major arches and high-angle reverse faults.

Volcanic and intrusive rocks of the Sverdrup Basin magmatic province remain virtually unexplored for their economic potential. A comparison of the attributes of the SBMP with the Noril'sk, Voisey's Bay and Midcontinent Rift regions, however, suggests many similarities. The following observations will be illustrated in the talk:

- The presence and eruptive style of the flood basalt province, and the evidence for widespread intrusion of basaltic magma during continental rifting.

- The possibility that major sills that could have acted as 
magma reservoirs or conduits.

- The geochemical evidence for a mantle plume origin and the selective crustal contamination of basaltic magmas.

- The presence of black shales and evaporites in the stratigraphic succession.

- The identification of major faults and their intersection with volcanic systems.

- The presence of magnetic anomalies that could represent large, deep mafic bodies.

- The possibility that lithospheric-scale faults acted as magma conduits.

The striking similarities to regions such as Noril'sk promote the Sverdrup Basin as a natural laboratory to test the exploration guidelines proposed by Naldrett (1992), for areas of flood basalt volcanism. We discuss the application of this exploration model to the SBMP, in light of the existing geochemical database, economic indicators, and remaining gaps in geoscience knowledge.

\title{
Kimberlites in northern Labrador and Nunavut: do they have exotic relatives in Québec?
}

\author{
Derek H.C. Wilton \\ Department of Earth Sciences, Memorial University of Newfoundland, St. John's, NF AlB $3 X 5$ \\ $<$ dwilton@sparky2.esd.mun.ca $>$
}

A NATMAP project in 1995 located at least eight so-called ultramafic lamprophyre dykes in the Cape Chidley area of northernmost Labrador and Nunavut. They were described as dark-grey to black, recessively weathering dykes with local olivine nodules. Thin-section studies revealed them be alkalic, olivine-phlogopite-carbonate-perovskite rocks. The dykes were post-tectonic and grouped with Phanerozoic dykes.

Copper Hill Resources Ltd. (CUHL) of St. John's, NF, staked the area and sampled six of the dykes. The whole rock samples, weighing up to $18.5 \mathrm{~kg}$, were crushed and separated into heavy mineral concentrates (HMC) from which garnet, clinopyroxene, orthopyroxene, olivine, ilmenite and chromite indicator minerals were picked and analysed by electron microprobe at a commercial laboratory.

Based on the mineralogy of the samples collected, two of the dykes are classified as kimberlite and the remainder as lamprophyres, though they have some mineralogical features in common with the kimberlites. Sample size was very small for definitive determinations; for instance, one kimberlite had a strike extension, which was classified as lamprophyre.
Within the kimberlites, the following mineral phases were identified: (1) Iherzolitic, eclogitic and megacrystal garnet (megacrystal garnet was also found in some of the lamprophyres), (2) clinopyroxene which plots in Fipke's diamondiferous CPX domain (as does one lamprophyre), (3) orthopyroxene with $<1 \%$ to $1.5 \% \mathrm{Al}_{2} \mathrm{O}_{3}$, and (4) olivine with Fo contents of $\sim 88-92$ (some of the lamprophyres have two populations of olivine with clusters of similar high Fo values). Orthopyroxene and clinopyroxene geothermobarometers indicate a harzburgite chemistry for some mineral separates and also that the postulated geotherm for the intrusive history of the dykes is permissive of diamond stability.

A soil geochemical sample collected over one dyke yielded significant pyrope, chrome diopside and olivine and minor amounts of indicator minerals were recovered from small stream sediment samples.

Seventy-five $\mathrm{km}$ southwest of these dykes, in the Abloviak Shear zone, Ungava Bay, Québec, Twin Gold Ltd. has been conducting an active exploration program in possibly similar kimberlite dykes from which they report significant concentrations of diamonds.

\section{New lithogeochemical and $\mathrm{Pb}$ isotope data from the Buchans area, central Newfoundland}

\author{
L.S. Winter and D.H.C. Wilton \\ Department of Earth Sciences, Memorial University of Newfoundland, St. John's NF AIB $3 X 5$ \\ $<$ dwilton@sparky2.esd.mun.ca $>$
}

Recent geochemical and $\mathrm{Pb}$ isotope research carried out in the Buchans mining camp and funded by Buchans River Ltd. and Billiton Exploration Canada Ltd., has revealed a number of interesting features. These include demonstration of a definite geochemical difference between foot-wall and hanging-wall rocks at the Lucky Strike ore-body. The foot-wall rocks are slightly calc-alkaline-transitional dacites, whereas the hanging-wall rocks are calc-alkaline rhyodacites. The presence of these two distinct bounding lithologies to the ore horizon suggests that hydrothermal exhalation/ore deposition occurred in a period of relative quiescence during which the magmatic affinities of the enclosing volcanic rocks changed. This delineation of hanging-wall/foot-wall chemistries could prove to be an effective exploration tool for
Buchans-style $\mathrm{Zn}-\mathrm{Pb}-\mathrm{Cu}$ mineralization.

Felsic volcanic samples from the Buchans East area are tholeiitic to transitional, whereas those in the Buchans camp proper generally are calc-alkaline to calc-alkaline-transitional suggesting that the eastern rocks are not Buchans Group sensu stricto, but are composites of Buchans Group and tholeiitic sequences.

The new geochemical data also raise some questions about the whole nature of the Buchans Group as presently defined and suggest that the area may be petrogenetically more internally complex than previously thought. The REE and HFSE data for basalts from the Clementine West area are tholeiitic and completely unlike the typical Buchans River Formation. Yet $\mathrm{Pb}$ isotope data, base metal and $\mathrm{Ba}$ contents, 
alteration assemblages and the overall lithological context of the samples suggest that they are coeval parts of the Buchans rocks.

The prominent quartz rhyolite (PQR) is also an enigma. Wherever sampled, east or west of Buchans, it is definitively calc-alkaline with elevated $\mathrm{Ba}$ contents and resembles the "typical" calc-alkaline signature of the Buchans River Formation; this implies at least a spatial link between the Buchans camp and the Buchans east area. The PQR appears to be in-situ, possibly intrusive, at many localities in the Buchans area, but is also the apparent source of the Sandy Lake Formation epiclastic sequence. REE and HFSE data also suggest that spatial geochemical variations occur in the PQR itself. In the Lucky Strike area, the PQR has the most enriched
Th and $\mathrm{Zr}$ anomalies of all samples analysed.

$\mathrm{Pb}$ isotope data suggest that the $\mathrm{Pb}$ isotope compositions in galena separates define (a) distinct groupings and (b) a mixing line between the groupings. The Buchans ore bodies themselves define a very tight clustering. The mixing line ranges from most primitive (least radiogenic) in the Tower Zone to most radiogenic in the Middle Branch East - Mary March zones. Other Buchans region samples plot with $\mathrm{Pb}$ from the tholeiitic Skidder Prospect suggesting that the $\mathrm{Pb}$ in the Buchans region represents a mixture between a least radiogenic, Skidder-type tholeiitic mafic environment and a more radiogenic calc-alkaline (?) felsic environment.

\title{
Trace element zoning in calcic, pelitic garnet: garnet growth histories and $\mathrm{Cr}$ immobility
}

\author{
Panseok Yang and Toby Rivers \\ Department of Earth Sciences, Memorial University of Newfoundland, St. John's, NF AIB $3 X 5$ \\ <pyang@morgan.ucs.mun.ca>
}

X-ray composition maps and profiles for major, minor, and trace elements have been made for four calcic metapelitic garnet grains from the Grenville Province of western Labrador, using electron microprobe and laser ablation ICP. MS. Metamorphic grade in the area ranges from greenschist to upper-amphibolite facies. Zoning patterns for $\mathrm{Ca}, \mathrm{Mg}, \mathrm{Mn}$, and $\mathrm{Y}$ are approximately concentric, defining growth-zoning profiles that were slightly modified by diffusional homogenization at the metamorphic peak. The zoning pattern for $\mathrm{Cr}$, in contrast to those for all other elements, displays zoning patterns parallel to inclusion trails of the garnets, indicating that the garnet overprinted a fabric defined by $\mathrm{Cr}$ rich (chlorite \pm muscovite \pm epidote \pm graphite) and $\mathrm{Cr}$-poor (quartz \pm plagioclase) layers (overprint zoning). Garnet porphyroblasts from upper amphibolite facies show a textural unconformity defined by inclusion-free rims, which coincides with changes in the garnet composition for both major and trace elements, including $\mathrm{Cr}$. The textural unconformity inferred to represent a change in the garnet-forming reaction, possibly also associated with a reduction in the growth rate of the garnet. Preservation of original $\mathrm{Cr}$ variations within the garnet demonstrates that diffusion of $\mathrm{Cr}$ was significantly slower than for the other elements, both during garnet growth and subsequent diffusional re-equilibration. This study explains previously observed non-systematic $\mathrm{Cr}$ zoning in metamorphic garnet and irregular partitioning of $\mathrm{Cr}$ between co-existing metamorphic mineral pairs. The $\mathrm{Cr}$ overprint zoning potentially offers an alternative way to interpret the microstructural history of complexly deformed samples in which garnet growth occurred under greenschist and/or amphibolite facies conditions. 